\title{
The Effectiveness of the "Image Processing" Learning Practice Learning Model in Informatics Engineering Diploma Program
}

\author{
Herry Sulendro Mangiri, Herminarto Sofyan, Adhi Susanto
}

\begin{abstract}
This study aims to analyze the effectiveness of practical learning models for Image Processing Subjects in the Diploma III Informatics Engineering program that suits the needs of the industrial community. The research method used in this study is ex post facto with data collection techniques using a questionnaire.

Research results and data analysis from the effectiveness test of learning model learning. showed that the results of the study were obtained in the amount of $12.5 \%$ of respondents rated the practice learning model in the image processing course included in the category of quite effective, other respondents in the amount of $25 \%$ rated that the learning model used was included in the effective category. Whereas $62.5 \%$ considered that the learning model developed was included in the very effective category. The analysis shows that the largest percentage is $62.5 \%$ in the analysis of the effectiveness of learning using the learning model included in the category of very effective. Thus it can be concluded that the learning model developed is included in the very effective category.

Reliability test for the two validators after validating the model of teaching practice in Image Processing courses, in the process of producing the first table of statistical reliability which shows the output if estimated using the Alpha coefficient. The table shows a satisfactory Alpha reliability of 0.385 . In the second table is the output of the analysis through ANOVA. From these outputs, there is no difference in ratings between rater $(p>0.05)$ and the third table shows ICC output with less satisfactory inter-rater reliability, ie $r x x=0.015$, thus the results of the reliability test of the teaching practice model of reliable Image Processing courses .
\end{abstract}

Keywords : Practice Learning, Image Processing, Informatics Engineering.

\section{INTRODUCTION}

Education and the industrial world today has become an inseparable relationship from one another. Industrial world dependence on the real world of education and vice versa.

Manuscript published on November 30, 2019.

* Correspondence Author

Herry Sulendro Mangiri*, Post Graduate Program, Universitas Negeri Yogyakarta , Yogyakarta, Indonesia. Email: ch2mangiri@gmail.com

Herminarto Sofyan, Faculty of Engineering, Universitas Negeri Yogyakarta, Yogyakarta, Indonesia. Email: hermin@uny.ac.id

Adhi Susanto, Faculty of Engineering, Universitas Negeri Yogyakarta, Yogyakarta, Indonesia. Email: adhisusanto@gmail.com

(C) The Authors. Published by Blue Eyes Intelligence Engineering and Sciences Publication (BEIESP). This is an open access article under the CC-BY-NC-ND license http://creativecommons.org/licenses/by-nc-nd/4.0/
The industrial world needs educated workers who have expertise, ability and skills in running the industry. Output from educational institutions is highly needed by the industrial world, in other words graduates from educational institutions as workers in the industry. The role of educational institutions as a place of the educational process in building human resources is very important. The use of appropriate learning methods in producing ready-made personnel is also very influential. The learning model is a learning pattern or structure that is structured and designed, established, and evaluated systemically to achieve the learning goals desired by educators. The term model itself can be interpreted as an imitation of an actual object. The model can also be interpreted as a conceptual or procedural example of a program, system, or process that can be used as a reference or creative guide in meeting the needs of students.

The development of the world labor market has certain standards for its workers, thus there is an adjustment to the world of education through educational institutions. Forms of Academic and Polytechnic educational institutions are forms of institutions that prioritize skills and expertise in the mastery of practices or educational institutions based on TVET (Technical and Vocational Education Training).

The outputs from the forms of Academic and Polytechnic institutions are graduates who are ready to use in Industry, both forms of higher education institutions have several study programs or majors based on Technical and Vocational Education Training (TVET). The existence of available study programs or majors such as the Informatics Engineering diploma program and the allied ones have the highest interest in each educational institution, as happened in Private Universities in the city of Solo who still rely on Diploma III Program [1]. The DIII program at the Indonusa Polytechnic in Academic Year 2017/2018 is still high, until now the number of applicants has reached 540 people.

One of the supporting subjects in the Informatics Engineering Diploma III study program is the Image Peocessing course. Image Peocessing courses are included in the family of computer graphics. The existence of courses presented in an educational institution Diploma of Informatics Engineering Study Program in the learning process is demanded for mastery of practice. The practice learning model used in vocational institutions is also different from the methods of learning practices in non-vocational institutions.

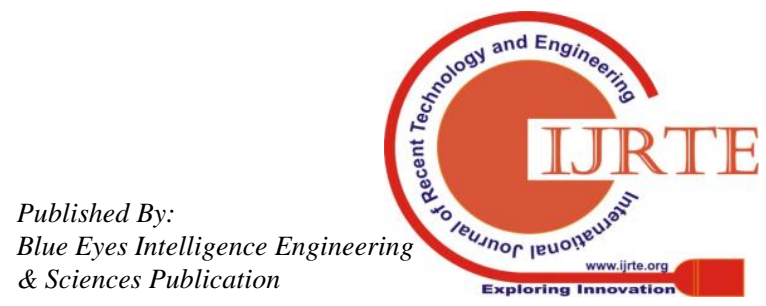




\section{The Effectiveness of the "Image Processing" Learning Practice Learning Model in Informatics Engineering Diploma Program}

The current practical learning model still revolves around analyzing images or objects that are recorded. Meanwhile, the developers are handed over to students to be utilized as needed.

The results of observations on supporting the model of Image Processing practice learning courses in the form of practicum modules that have been carried out in several universities, such as several examples of practicum modules that have been implemented: Image Processing Practicum Module of ITS Polytechnic [2], Image Processing practicum modules at Pandjajaran University [3 ], Image Processing practicum module at Computer University, Image Processing practicum module at Panca Budi Development University, Image Processing practicum module at Malang National Institute of Technology, and several universities that hold Informatics Engineering diploma programs.

In the initial observation also found several universities both public and private, the availability of Image Processing courses has not been well accommodated. This can be known from the Curriculum of each Informatics Engineering D III Study Program in each tertiary institution such as: Curriculum D III Informatics Engineering PIKSI Bandung Polytechnic, D III Curriculum Informatics Engineering Dian Nuswantoro University Semarang, DIII Curriculum Informatics Engineering Muhammadiyah University Sidoarjo [4] , curriculum D III UNS Informatics Engineering, curriculum D III AMIK BSI Informatics Engineering Jakarta, curriculum D III Informatics Engineering Sangga Buana University-YPKP Bandung, curriculum D III Informatics Engineering Bengkalis State Polytechnic, curriculum D III Informatics Engineering STIMIK Sinar Nusantara, curriculum D III AMIK BSI Informatics Engineering Purwokerto and curriculum D III STIMIK Informatics Engineering Indonesia Mandiri.

Referring to the existing practice learning model, when compared with the application of Image Processing courses in various disciplines according to Rinaldi Munir (2004: 12), namely: (1) the field of medicine, (2) the field of industry, (3) the field of commerce, (4) military, (5) biology, and many other fields. You will see incompatibility with the many applications in the industry about image processing. The number of applications and functions of Image Processing Subjects requires a model of practical learning in accordance with current industry conditions.

Based on the description above, the educational institutions that hold the Informatics Engineering diploma program both public and private that present Image Processing courses must be equipped with mastery of practice to improve their skills and abilities. So learning existing practices must be evaluated by measuring the effectiveness of practical learning in image processing subjects.

\section{LITERATURE REVIEW}

\section{A. Vocational Learning}

The challenges of vocational education learning continue to develop in line with the changing dynamics of the context of the world of work, changes in the economic system, changes in the direction of development policies,

technological-engineering, scientific, social and cultural developments. TVET learning in meeting social efficiency demands directs education and training activities as an active process of acquiring competencies and skills in: (1) understanding the requirements and demands of the world of work; (2) doing routine work and mastering daily work procedures; (3) increase work productivity; (4) applying work safety standards; (5) creatively developing design and engineering; (6) work in teams collaboratively; (7) digital multi media literacy, letters, symbols; (8) critically analyzes situation and problem solving; (9) processing information and computing; (10) understanding the role of science and technology in society; (11) understanding the development of global, regional and local environments; (12) understanding the importance of efficiency, quality, added value, appearance and marketability; (13) morality, ethics, sensitivity and social justice; (14) managing income as a future investment; (15) has an entrepreneurial spirit; and (16) always think positively [5].

The specific purpose of the implementation of TVET is very broad in line with the needs of the nation's self-development as the development of basic resources, community economic development, and the vision and mission of national development. TVET is held in the context of preparing students to enter work life, choosing work, developing capacity, developing high skills in selected jobs [6], continuously developing the ability to solve problems through work life [7], provision of educational experience to support various possible transitions from one job to another; creating their own employment as a new entrepreneur [7]. TVET is concerned about education and training efforts to help students in identifying jobs that are suitable for their careers, are fun, productive, and make a positive contribution both to employers and to themselves as workers.

XXI Century learning has shifted toward students as centers of education, self learning, self-actualizing processes, focus on how to learn, self rewarding, multiple sources of learning, networked learning, lifelong and everywhere, unlimited opportunities, world class learning, local and international outlook [8]. TVET learning theory has developed far in line with the development of work career demands in the XXI Century. Classical learning theory based on psychology no longer satisfies enough in analyzing the learning needs of TVET. TVET learning requires Contemporary Learning Theory such as life-based learning theory, social partnerships, adult learning, mature competency development as a collective process, competence formation as learners network members, work-based learning (work-based learning), workplace learning, direct learning in working life. TVET learning is no longer enough on capacity building (capacity building). Educating and training students who are capable of working if they do not want to work will be useless [5].

\section{RESEARCH METHODS}

Data collection techniques used in this study were the questionnaire method.

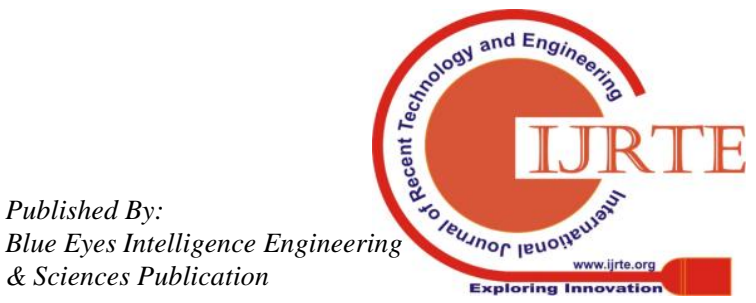


This research was conducted at the Central Java Veterans IKIP college which is now becoming the Ivet University which has an Informatics Engineering Vocational Education program. This research was conducted within 10 months.

\section{RESULTS AND DISCUSSION}

\section{A. Result}

The following are the results of the study to see the effectiveness of the practical learning model used in the practice of image processing courses in the fourth semester students of the Informatics Engineering Vocational Education year of 2018/2019 as follows:

Table 23 Effectiveness of learning image processing practices

\begin{tabular}{|c|c|}
\hline Category & Percentage \\
\hline Effective enough & $12.5 \%$ \\
\hline Effective & $25.0 \%$ \\
\hline Very Effective & $62.5 \%$ \\
\hline Total & $100.0 \%$ \\
\hline
\end{tabular}

In the table is the result of research and data analysis of the effectiveness test of learning models. The table shows that the results of the study are as many as $12.5 \%$ of respondents rate the practical learning model in the image processing course included in the category of quite effective, other respondents namely 25\% rate that the learning model used is included in the effective category. Whereas $62.5 \%$ considered that the learning model developed was included in the very effective category. The analysis shows that the largest percentage is $62.5 \%$ in the analysis of the effectiveness of learning using the learning model included in the category of very effective. Thus it can be concluded that the learning model developed is included in the very effective category.

Reliability test for the two validators after validating the model of teaching practice in Image Processing courses, in the process of producing the first table of statistical reliability which shows the output if estimated using the Alpha coefficient. The table shows a satisfactory Alpha reliability of 0.385. In the second table is the output of the analysis through ANOVA. From these outputs, there is no difference in ratings between rater ( $p>0.05)$ and the third table shows ICC output with less satisfactory inter-rater reliability, ie $\operatorname{rxx}=0.015$, thus the results of the reliability test of the teaching practice model of reliable Image Processing courses .

\section{B. Discussion}

The place of research was conducted at IKIP Veterans in Central Java, with 2 groups of students with different academic years, the total sample of students was 16 students in the fourth semester of academic year 2017/2018 and 16 students of Semester IV Academic Year 2018/2019 with the specifications of students who ever took or programmed Image Processing subject.

The results of this study are in the form of an analysis of the effectiveness of the practical learning model for Image Processing courses in the Diploma in Informatics Engineering Program. In literature studies and in the field the application of this practical learning model requires a review and analysis of the conditions that have occurred and which have taken place so far. This practical learning model is supported by learning material and learning media. Learning media used to carry out practical learning activities in the form of; Practical Job Sheet for students, practical instructions for students, practical lecture unit for lecturers, Semester Learning Plan (RPS) and lecture material (diktat).

From the results of the questionnaire lecture material supporting the learning of this practice is very feasible and effectively used when guiding practical activities. The teaching material in the form of a textbook is very helpful for lecturers, because the content in the textbook is very applicable and contains many programming examples for Image Processing courses. Students easily get a solution by discussing the problem of the practice of Image Processing programming to lecturers in the course. The impact of this is automatically the ability and skills of students to be increased and in accordance with the objectives of learning the practice of Image Processing courses.

\section{Conclusion}

Based on the results of the product development model of teaching practice Image Processing courses are very effective in the development of technology in the industrial world. The effectiveness level of the Image Processing practice learning model is generated from the development of the lecture learning model into a practical learning model that is applied to students. The needs of the industrial world for skilled and proficient personnel in the field of Image Processing can be answered by graduates from tertiary institutions. The development of the industrial world will always be followed by developments in the world of education by applying an effective practice learning model in every subject, including the Image Processing subject. The application of practical learning models in each course will increase the number of hours of practice lectures compared to the total teaching load of theoretical lectures or lecture learning models to $60 \%-70 \%$ of practical learning activities compared to $40 \%-30 \%$ of theoretical learning activities.

\section{SUGGESTION}

Based on the research results and conclusions above, the authors compile suggestions that later in the future can be used as a consideration for similar research. Suggestions that can be submitted that can be used as consideration are as follows:

1. This educational institution includes the LPTK which still stands in Central Java, where the policy of the institution must be able and courageous to make a breakthrough about adopting industrial regulations into institutional regulations especially in vocational study programs / study programs within the Central Java IKIP Veterans Institute (Ivet University), so a Vocational campus was formed with industry-based conditions and environment.

2. Institutions are able to provide practice facilities and infrastructure that are always updated according to technological developments and in accordance with the needs of the industrial world from software to hardware, although basically the world of education will not be able to precede technological advances in the industrial world but at least be able to keep up with technological developments in the world industry.

Published By: and $E_{n}$

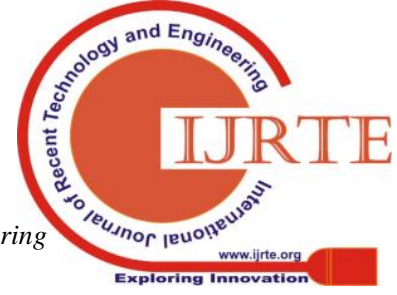




\section{The Effectiveness of the "Image Processing" Learning Practice Learning Model in Informatics Engineering Diploma Program}

3. Institutions carry out industrial cooperation in lecturing and student internships. With this collaboration activity students can conduct lectures in the industry directly for certain subjects especially those dealing with Image Processing technology. Student internships are conducted in the form of industrial internship with 3-12 months.

4. The Institute encourages lecturers and students to attend BNSP certified workshops or training to improve skills with funding sourced from the institution.

5. Students as users of the model of Image Processing practice teaching practice at the time of the implementation of the practice are still not many disciplines in participating in practical learning, namely when entering the practice room not on time. This needs an initial explanation to the student by the lecturer about the rules that must be obeyed before carrying out practical activities. Regarding the lack of scrutiny of students in reading instructions or instructions in existing examples, the instructor lecturer must really guide students during the practice. In terms of assembling practical tools students are still often careless in installation, especially when installing external equipment that is connected to a computer, so that the practical equipment cannot function properly. Therefore students are required to be careful in reading instructions when installing software.

6 . The number of students in one class is limited to around 24-30 students, this is because the practice learning process can be optimal with the number of students in one class not too large. This is for private universities to be inappropriate because there will be large funding for practical activities, so not many private universities are able to carry out study programs / Study Programs. This causes only public universities that can establish study programs / study programs in the Informatics Engineering diploma program, so that graduates are limited and the need for labor for industry will always decrease.

\section{REFERENCES}

1. A. Prawitasari, "Perguruan Tinggi Swasta Di Solo Masih Andalkan Program DIII," www.solopos.com, solo, Jul-2017.

2. N. Ramadijanti, "Image Processing - Politeknik Elektronika Negeri Surabaya." [Online]. Available: https://www.google.com/url?sa=t\&rct=j\&q=\&esrc=s\&source=web\&cd =2\&ved=2ahUKEwia6pSMndnlAhVZAXIKHS3pBAkQFjABegQIAx AC\&url=http\%3A\%2F\%2Fnana.lecturer.pens.ac.id\%2FCitra09\%2FD ay1.pdf\&usg=AOvVaw3717RHDcDuGatNaKz-3Tot.

3. S. Hadi, "modul praktikum pengolahan citra 2016." [Online]. Available: https://www.google.com/url?sa=t\&rct=j\&q=\&esrc=s\&source=web\&cd =1\&cad=rja\&uact=8\&ved=2ahUKEwjck6q_ndnlAhXUbCsKHaB-CfI QFjAAegQIABAC\&url=http\%3A\%2F\%2Fsetiawanhadi.unpad.ac.id\% 2FWelcome\%2520to\%2520Setiawan\%2520Hadi\%2520homepage_fil es\%2Fpendidikan\%2FGenap1516\%2FPC\%2FmodulPCD-2016.pdf\&u sg=AOvVaw1qm63XrCEIRRM8mJ1KLxqb.

4. LP3IK, "kurikulum DIII Teknik Informatika."

5. P. Sudira, TVET Abad XXI Filosofi, Teori, Konsep, dan Strategi Pembelajaran Vokasional. yogyakarta: UNY Press, 2016.

6. M. Pavlova, "Technology and Vocational Education for Suistanable Development," Springer Sci., 2009.

7. H. A. \& M. N.Y, "Towards Achieving TVET for All: The Roleof the UNESCO-UNEVOC International Centre for Tehcnical and VocationalEducation and Training," Int. Handb. Educ. Chang. World Work. Bridg. Acad. Vocat. Learn., 2009.

8. Y. . Cheng, "New Paradigm for Re-engineering Education, Globalization, Localization and Individualization," Springer, 2005.

9. E. C. Bruce Joyce, Marsha Weil, Models of TeachingModel-model pengajaran. Yogyakarta: Pustaka Pelajar.

10. P. Forsyth, Jangan Sia-siakan Waktumu. (alih bahasa). Yogyakarta: PT. Garailmu.

11. M. W. dan E. C. Joyce, Bruce, Models of Teaching (Model-model Pengajaran Edisi Kedelapan). Yogyakarta: Pustaka Belajar., 2009.

12. D. P. Eggen, P. D. dan Kauchak, Strategies for Teachers Teaching Content and Thinking Skills. Boston: Allyn \& Bacon., 1993. 